\title{
QUANTITATIVE ASSESSMENT OF SOUTH AFRICA'S INVENTIVE OUTPUTS: INTERNATIONAL PATENT ANALYSIS
}

\author{
A. Pouris \\ Institute for Technological Innovation \\ University of Pretoria, South Africa \\ anastassios.pouris@up.ac.za
}

\begin{abstract}
This article aims to identify and analyse the inventive activity of South Africans as it is manifested in the form of patents. Patents are used internationally as indicators of national and corporate inventive activity, but they rarely are reported in the context of the South African reality. Inventive activity is analysed in terms of patents awarded to South African inventors by the USA patent office (USPTO). South African inventors are identified to apply and receive approximately 110 patents per year from the USPTO. Analysis of the patents according to technological classes identifies classes that indicate the country's strengths. South Africa is ranked fourth internationally in technological class "Chemistry: FischerTropsch Processes; or Purification or Recovery of Products Thereof"; and twelfth in "Specialised Metallurgical Processes". It is argued that government should support further innovation in the country's strong inventive areas. Corporate patent analysis identifies the most inventive organisations in the country; co-inventive analysis identifies the countries with which South Africans cooperates; and international comparisons set South Africa in an international context. An important finding is that South Africa appears not to have participated in the international explosion of patents during the last twenty years. It is suggested that neither the policy environment nor factors determining technological fertility have changed in South Africa during the last two decades.
\end{abstract}

\section{OPSOMMING}

Hierdie artikel het ten doel om Suid-Afrika se innoverende aktiwiteite in die vorm van patente te identifiseer en te ontleed. Innoverende aktiwiteite word in terme van patente, wat aan Suid-Afrikaanse innoveerders deur die VSA se patente-kantoor ("US Patent Office USPTO") toegeken word, ontleed. Suid-Afrikaanse uitvinders word genader om aansoek te doen en ongeveer 110 patente word jaarliks deur USPTO toegeken. 'n Ontleding van die patente identifiseer klasse wat die land se sterk punte aantoon. Suid-Afrika is op internasionale vlak vierde in die tegnologiese klas Chemie: Fischer-Tropsch-prosesse; of Suiwering of Herstel van Produkte Daarvan geplaas, en twaalfde in Gespesialiseerde Metallurgiese Prosesse. Daar word gestel dat nóg die beleidsomgewing nóg die faktore, wat tegnologiese vrugbaarheid bepaal, gedurende die afgelope twee dekades in Suid-Afrika verander het. 


\section{INTRODUCTION}

Monitoring and evaluating the various facets of the scientific enterprise is a necessary and integral part of science policy. Rising costs of research and development, and competing disciplinary claims for financial resources, require intelligent allocation of resources, which presupposes knowledge of the activities and performance of the innovation system.

One of the most efficient and objective methods of assessing research and innovation performance is through scientometric indicators. An indicator is defined [1] as "statistics of direct normative interest which facilitate concise, comprehensive, and balanced judgments about the condition of major aspects of a society. It is in all cases a direct measure of welfare, and is subject to the interpretation that, if it changes in the 'right' direction while other things remain equal, things have got better or people have got better off". Scientometric analysis, the quantitative study of the innovation system, is based mainly on bibliometric and patent indicators. In bibliometrics the number of publications in a field is considered to be an indicator of research activity. Similarly, in patent analysis the number of patents awarded to an institution or a country is used as an indicator of technological activity. Patent indicators - within the science and technology (S\&T) context - are used to measure inventive performance, diffusion of knowledge, and internationalization of innovative activities, across countries, firms, industries, technology areas, etc.

The philosophy underlying the use of bibliometric indicators as performance measures has been summarized in De Solla Price's statement that "for those who are working at the research front, publication is not just an indicator but, in a very strong sense, the end product of their creative effort". [2]

Of course, there are many trained scientists who are not required to publish. They may perform managerial or administrative functions, they may teach available knowledge, or they may apply existing knowledge in making new products and in providing services. The common characteristic of all these scientists is that they are far away from the research front. They provide the infrastructure for the producers of knowledge, and they exploit the end results of research and development. In any case, however, they cannot be considered as 'researchers'.

The same way in which scientific articles are accepted as a legitimate reflection of scientific research, patents are accepted as a reflection of technological achievements. Griliches [3] has pointed out that "patent statistics remain a unique source for the analysis of the process of technical change. Nothing else even comes close in the quantity of available data, accessibility, and potential industrial, organizational, and technological detail".

Patents fulfil two roles: they provide inventors with legal protection for novel products and processes, and simultaneously they ensure that the knowledge of these products and processes becomes available to society. In this way both private and public interests are served. Carr [4] describes the concept of patent as follows:

A patent is an exclusionary right granted by a government entity. The concept behind the United States patent system is that the government grants statutory protection to an inventor in the form of exclusionary rights for a period of years in return for a disclosure of the creativity of the grantee. The exclusionary rights granted by the patent are the rights to exclude others from making, using or selling the patented invention throughout the United States and its territories for a period of 17 years. In exchange for these rights, the patent discloses and teaches technical knowledge relating to the invention. During the life of the patent, scientists and other inventors benefit from the disclosure of prior art information by avoiding repeating efforts to discover that which is already known. After the patent expires, the invention belongs to the public and anyone can make, use or sell the invention without permission of the patentee. 
Patent analysis possesses a number of strengths that facilitate their universal use as scientometric tools. They are highly reliable because they are well defined and unambiguous. They facilitate detailed categorisation and thus make possible the study of scientific and technological fields and sub-fields. Finally, they make possible international comparisons. The Organisation for Economic Cooperation and Development (OECD) provides guidelines for the use of patents in their relevant manual. [5]

In the United States of America the National Science Foundation [6] is using bibliometrics, patent, and trade in high technology analysis to monitor the health of American science and technology on a continuous basis; in Europe the European Commission [7] is using similar approaches in order to monitor the health of the European innovation system; and the $\mathrm{OECD}[8]$ is using the indicators for monitoring and comparative purposes.

In South Africa, policy researchers rarely utilize patents as a source of information [9] [10]. The purpose of this document is to identify the performance of the inventive component of the South African innovation system as it is manifested in the analysis of patents.

\section{METHODOLOGY AND DATA SOURCES}

Patent analysis - within the science and technology (S\&T) context - is used to measure inventive performance, diffusion of knowledge, and internationalization of innovative activities, across countries, firms, industries, and technology areas. Porter et al. [11] argue that patent indicators are the most appropriate for defining the innovative capacity of countries, and that international patenting is strongly correlated with alternative measures of innovative output such as the number of scientific journal articles, and also with outcome measures such as a country's market share in high-technology industries.

The patents most often utilized internationally for this type of analysis are those awarded by the United States Patent Office (USPTO). Although most countries in the world have their own patent authorities, the use of the USPTO provides a number of advantages. First, in the majority of the patent offices, patents are not examined for originality, usefulness, or novelty. The South African patent office is one of these.

Consequently, counting and comparing patents awarded by different patent offices in different countries may be misleading because of differences in the criteria used, the ease with which patents are awarded, bias towards local patents, etc. The obvious way to avoid such shortcomings is to use a common denominator such as an external patent system with an objective approach to awarding patents - i.e. the USPTO. The USPTO examines claims according to a number of criteria. These are [12]:

- Subject matter: An invention must fall into one of the categories that the patent law uses for patentable subject matter.

- Utility: An invention must fulfil the substantive requirement of 'utility'. An invention must perform a designed function or achieve some minimum human purpose.

- Novelty: An invention has to be novel.

- Non-obviousness: The knowledge in the technological field at the time of invention must not make the invention obvious to one of ordinary skill in that area.

- Definiteness: One skilled in the art must understand the limits of the invention based on the claim language.

Second, the US represents the most important single market for technology-related sales, and thus is a key drawing card for technology-based products. Owners of important commercial inventions will make sure that they are protected in the USA market. Third, the 
costs involved and the complexity of filing foreign patents in the USA tend to screen out trivial patents.

Although patents facilitate the development of a number of useful indicators, they have a number of drawbacks. Patented inventions do not necessarily represent all the inventions produced in a country or organization. Many inventions are not patented because there are other barriers to entry (e.g. lack of brand names among the competitors), because inventors may undertake other measures of protection (e.g. the encapsulation of products in epoxy resin to deter imitation), or because inventors consider that the invention will be profitable even if imitators may appear in the foreseeable future. Similarly, high costs for applications or monitoring infringement, as well as lack of appreciation, are additional reasons that may limit the number of patents from a particular country or organisation.

The USPTO classifies the patents in different classes and subclasses. The class breakouts represent major divisions of technology in the US Patent Classification System (USPCS). The USPCS currently contains approximately 460 classes and 150,000 subclasses. The classification of the patents to subclasses is done according to information disclosed in the patent. If more than one technology is identified as pertinent to the patent, one subclass is designated as the primary classification, and the remainder are designated as crossreference classifications. Counting patents by primary classification ensures that each patent is counted only once. The residence of the first-named inventor listed on the patent grant determines patent origin.

Furthermore, the USPTO classifies patents as utility patents (i.e. patents for invention), reissue patents, plant patents, design patents, and statutory invention registrations and defensive publications. In our investigation we utilize only utility patents.

Data for this analysis were received from the USPTO databases.

The South African applications in the Patent Cooperation Treaty (PCT) system are also reported. The PCT is an international treaty, administered by the World Intellectual Property Organization (WIPO), among more than 125 Paris Convention countries. The PCT makes it possible to seek patent protection for an invention simultaneously in each of a large number of countries by filing a single 'international' patent application instead of filing several separate national or regional patent applications. The granting of patents remains under the control of the national or regional patent offices in what is called the 'national phase'. Data have been obtained from the WIPO databases.

Briefly, an outline of the PCT procedure includes the following steps:

- $\quad$ Filing: The inventor files an international application, complying with the PCT formality requirements, in one language, and s/he pays one set of fees.

- International search: One of the world's major patent offices identifies the published documents that may have an influence on whether the invention is patentable, and establishes an opinion on the invention's potential patentability.

- International publication: As soon as possible after the expiration of 18 months from the earliest filing date, the content of the international application is disclosed to the world.

- International preliminary examination: One of the world's major patent offices may, at the inventor's request, carry out an additional patentability analysis, usually on an amended version of the application.

- Entry into the national/regional phase: After the end of the PCT procedure, the inventor starts to pursue the grant of the patents directly in the countries in which s/he wants to obtain them. 
The advantages of the PCT system, according to the WIPO web site, are as follows:

1. You have up to 18 months more than if you had not used the PCT to reflect on the desirability of seeking protection in foreign countries, to appoint local patent agents in each foreign country, to prepare the necessary translations and to pay the national fees;

2. you can rest assured that, if your international application is in the form prescribed by the PCT, it cannot be rejected on formal grounds by any PCT Contracting State patent office during the national phase of the processing of the application;

3. on the basis of the international search report and the written opinion, you can evaluate with reasonable probability the chances of your invention being patented;

4. you have the possibility during the optional international preliminary examination to amend the international application and thus put it in order before processing by the various patent offices;

5. the search and examination work of patent offices can be considerably reduced or eliminated thanks to the international search report, the written opinion and, where applicable, the international preliminary report on patentability that accompany the international application;

6. since each international application is published together with an international search report, third parties are in a better position to formulate a well-founded opinion about the potential patentability of the claimed invention; and

7. for you as an applicant, international publication puts the world on notice of your application, which can be an effective means of advertising and looking for potential licensees.

\section{SOUTH AFRICA'S INVENTIVE PERFORMANCE}

Figure 1 shows the number of patents awarded to South African inventors by the USPTO during the period 1963 to 2004 . The figure makes it clear that the number of South African patents granted by the USPTO increased until the early 1990s, and thereafter stabilized around a figure of 110 patents per year.

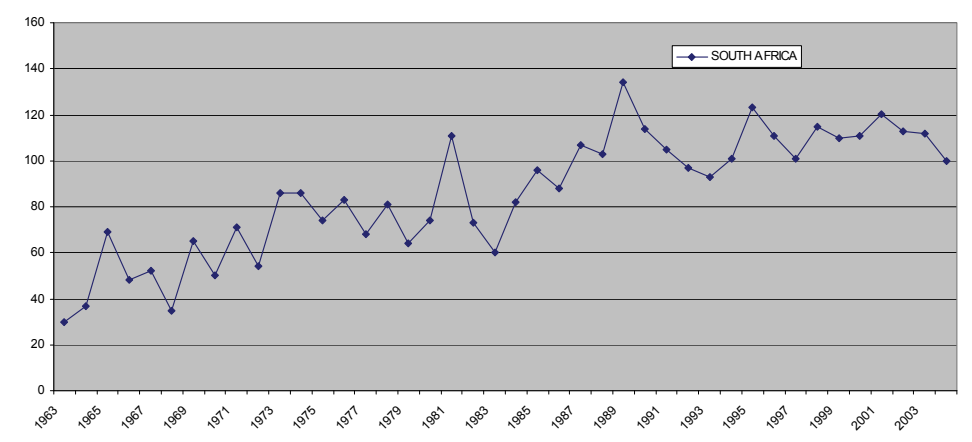

Figure 1: Number of South African patents - USPTO 1963-2004

Figure 2 shows the South African share in the USPTO for the period 1963-2004. The South African share of the total number of patents granted, and of the number of foreign patents granted, is shown. The graph of the number of South African patents compared with the number of foreign patents granted indicates a long-term decline. The number of patents granted to inventors from countries other than South Africa has increased much faster than 
the number of patents awarded to South African inventors, and thus the relevant ratio has declined from above $0.5 \%$ in 1965 to $0.1 \%$ in 2004. The ratio of the number of South African patents to the total number of granted patents - which is substantially lower owing to the large number of USA patents - shows a smaller variation because of a relative decline in the number of USA patents over time. We elaborate on the above issues in the discussion section.

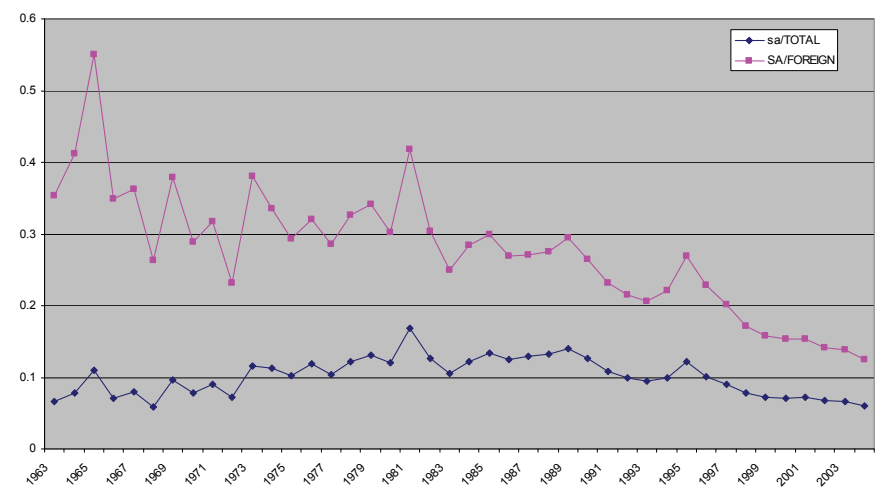

Figure 2: South African share of patents - USPTO 1963-2004

Table 1 shows the number of patents granted to South African inventors and inventors from a selected set of other countries during 1991, 1994, 2000, and 2004. The countries have been selected because they started the 1990s with fewer patents than South Africa; yet during 2004 they were producing substantially larger numbers. For example, Indian inventors were awarded 22 patents during 1991, while in 2004 they were awarded 363 patents - a more than 16-fold increase. Similarly, inventors from Hong Kong and Singapore (relatively small countries in terms of population) have been able to increase the number of their patents substantially within a decade.

\begin{tabular}{|l|c|c|c|c|}
\hline Granting year & 1991 & $\mathbf{1 9 9 4}$ & $\mathbf{2 0 0 0}$ & $\mathbf{2 0 0 4}$ \\
\hline South Africa & 105 & 101 & 120 & 100 \\
China, HK & 50 & 57 & 179 & 311 \\
Singapore & 15 & 51 & 218 & 449 \\
India & 22 & 27 & 131 & 363 \\
Ireland & 53 & 48 & 121 & 186 \\
Brazil & 62 & 60 & 98 & 106 \\
Norway & 111 & 126 & 248 & 243 \\
New Zealand & 41 & 37 & 107 & 142 \\
China, P Rep & 50 & 48 & 119 & 404 \\
Foreign Origin & 45,334 & 45,610 & 72,426 & 80,022 \\
\hline
\end{tabular}

Table 1: Number of USPTO patents granted to South Africans and residents of selected countries

Table 2 shows the top 30 countries in terms of number of patents granted during 2004. The table shows the number of patents granted to inventors from different countries as well as their relative share of patents in the USPTO. The USA tops the table with 84,271 patents, which constitute $51.5 \%$ of the total number of patents granted. Japan follows with 35,350 patents or $21.6 \%$ of the total. South Africa and Mexico are at the bottom of the list $\left(29^{\text {th }}\right.$ 
and $30^{\text {th }}$ positions respectively) with $0.1 \%$ of the patents each. It should be mentioned that South Africa was $21^{\text {st }}$ in 1991.

\begin{tabular}{|c|c|c|c|}
\hline & Country & Number & Percentage \\
\hline 1 & USA & 84,271 & $51.5 \%$ \\
\hline 2 & Japan & 35,350 & $21.6 \%$ \\
\hline 3 & Germany & 10,779 & $6.6 \%$ \\
\hline 4 & Taiwan & 5,938 & $3.6 \%$ \\
\hline 5 & South Korea & 4,428 & $2.7 \%$ \\
\hline 6 & United Kingdom & 3,450 & $2.1 \%$ \\
\hline 7 & France & 3,380 & $2.1 \%$ \\
\hline 8 & Canada & 3,374 & $2.1 \%$ \\
\hline 9 & Italy & 1,584 & $1.0 \%$ \\
\hline 10 & Sweden & 1,290 & $0.8 \%$ \\
\hline 11 & Switzerland & 1,277 & $0.8 \%$ \\
\hline 12 & Netherlands & 1,273 & $0.8 \%$ \\
\hline 13 & Israel & 1,028 & $0.6 \%$ \\
\hline 14 & Australia & 953 & $0.6 \%$ \\
\hline 15 & Finland & 918 & $0.6 \%$ \\
\hline 16 & Belgium & 612 & $0.4 \%$ \\
\hline 17 & Austria & 540 & $0.3 \%$ \\
\hline 18 & Singapore & 449 & $0.3 \%$ \\
\hline 19 & Denmark & 414 & $0.3 \%$ \\
\hline 20 & China, P. Rep. & 404 & $0.2 \%$ \\
\hline 21 & India & 363 & $0.2 \%$ \\
\hline 22 & China, HK & 311 & $0.2 \%$ \\
\hline 23 & Spain & 264 & $0.2 \%$ \\
\hline 24 & Norway & 243 & $0.1 \%$ \\
\hline 25 & Ireland & 186 & $0.1 \%$ \\
\hline 26 & Russia & 169 & $0.1 \%$ \\
\hline 27 & New Zealand & 142 & $0.1 \%$ \\
\hline 28 & Brazil & 106 & $0.1 \%$ \\
\hline 29 & South Africa & 100 & $0.1 \%$ \\
\hline \multirow[t]{2}{*}{30} & Mexico & 86 & $0.1 \%$ \\
\hline & TOTAL & 163,682 & $100 \%$ \\
\hline
\end{tabular}

Table 2: Number and percentage of patents granted in year 2004 by country of origin (USPTO): Top 30 countries

Table 3 shows the number of patents awarded to a number of corporations for comparative purposes. IBM, at the top of the list, was granted 3,248 patents during 2004. The table makes it clear that some corporations are substantially bigger in terms of patents than most countries. Canon, for example, is granted more patents than Belgium, Austria, and Denmark put together. During 2004 only $10.6 \%$ of the patents granted by USPTO went to individuals. Table 4 shows the patent classes in which South Africa was granted more than 10 patents 
from 2000 to 2004. Class 210, 'Liquid Purification or Separation' is top of the list with 26 patents. Class 424, 'Drug, Bio-Affecting and Body Treating Compositions', is second with 22 patents. The eight classes in the table (out of more than 400 classes) include $23 \%$ of the total number of patents granted to South African inventors.

\begin{tabular}{|l|c|}
\hline Organisation & Number \\
\hline IBM & 3,248 \\
Canon & 1,805 \\
HITACHI & 1,514 \\
TOSHIBA & 1,311 \\
Matsushita Elec Ind Co & 1,934 \\
NEC & 813 \\
Sony & 1,311 \\
Fujitsu & 1,296 \\
Samsung & 1,604 \\
Honda Motors & 736 \\
University of California & 422 \\
NASA & 102 \\
Microsoft & 629 \\
University of Texas & 99 \\
California Inst Technology & 135 \\
\hline
\end{tabular}

Table 3: Number of patents from prolific organisations (2004)

\begin{tabular}{|c|c|c|c|c|c|c|c|}
\hline Class & Class Title & 2000 & 2001 & 2002 & 2003 & 2004 & Total \\
\hline 210 & Liquid Purification or Separation & 7 & 9 & 5 & 4 & 1 & 26 \\
\hline 424 & $\begin{array}{l}\text { Drug, Bio-Affecting and Body Treating } \\
\text { Compositions (incl. Class 514) }\end{array}$ & 5 & 4 & 5 & 7 & 1 & 22 \\
\hline 340 & Communications: Electronic & 5 & 7 & 2 & 3 & 1 & 18 \\
\hline 075 & $\begin{array}{l}\text { Specialised Metallurgical Processes, } \\
\text { Compositions for Use Therein, } \\
\text { Consolidated Metal Powder Compositions } \\
\text { and Loose Metal Particulate Mixtures }\end{array}$ & 1 & 7 & 2 & 2 & 4 & 16 \\
\hline 423 & Chemistry of Inorganic Compounds & 2 & 3 & 3 & 2 & 3 & 13 \\
\hline 532 & $\begin{array}{l}\text { Organic Compounds (incl Classes 532- } \\
570 \text { ) }\end{array}$ & 2 & 2 & 3 & 3 & 3 & 13 \\
\hline 518 & $\begin{array}{l}\text { Chemistry: Fischer-Tropsch Processes; or } \\
\text { Purification or Recovery of Products } \\
\text { Thereof }\end{array}$ & 1 & 2 & 2 & 1 & 5 & 11 \\
\hline 198 & Conveyors: Power Driven & 3 & 3 & 2 & 0 & 2 & 10 \\
\hline
\end{tabular}

Table 4: Patents granted to SA inventors by technology class

Tables 5 to 12 present the ranking of countries according to the number of patents they have been awarded in specific technology classes. For example, Table 5 shows that in class 518, 'Chemistry: Fischer-Tropsch Processes; or Purification or Recovery of Products Thereof', the top country in the period is the USA with 145 patents. Japan, the United Kingdom, France, and South Africa follow with 15, 12, 11, and 11 patents respectively. South Africa shares fourth position with France. 


\begin{tabular}{|l|c|}
\hline Japan & $\mathbf{1 5}$ \\
United Kingdom & 12 \\
France & 11 \\
South Africa & $\mathbf{1 1}$ \\
Italy & 7 \\
Russian federation & 7 \\
Norway & 6 \\
Canada & 3 \\
China P. Rep. & 3 \\
Germany & 3 \\
Netherlands & 3 \\
South Korea & 2 \\
Belgium & 1 \\
Switzerland & 1 \\
Denmark & 1 \\
Trinidad/Tobago & 1 \\
\hline
\end{tabular}

Table 5: Top patenting countries in USPTO in class 518 (Chemistry: Fischer-Tropsch Processes; or Purification or Recovery of Products Thereof) 2000-2004

\begin{tabular}{|l|c|}
\hline Japan & 279 \\
Germany & 81 \\
Austria & 53 \\
Canada & 52 \\
Sweden & 41 \\
France & 37 \\
Australia & 29 \\
South Korea & 26 \\
Switzerland & 25 \\
United kingdom & 20 \\
South Africa & 16 \\
Finland & 11 \\
Venezuela & 9 \\
Italy & 8 \\
Norway & 8 \\
India & 7 \\
\hline
\end{tabular}

Table 6: Top patenting countries in USPTO in class 075 (Specialized Metallurgical Processes, Compositions for Use Therein, Consolidated Metal Powder Compositions, and Loose Metal Particulate Mixtures) 2000-2004 


\begin{tabular}{|l|c|}
\hline Japan & 511 \\
Germany & 378 \\
Canada & 236 \\
France & 184 \\
United Kingdom & 111 \\
Sweden & 87 \\
Australia & 76 \\
Netherlands & 71 \\
Taiwan & 57 \\
Finland & 52 \\
South Korea & 52 \\
Italy & 50 \\
Switzerland & 33 \\
Israel & 30 \\
Austria & 28 \\
South Africa & 26 \\
Belgium & 23 \\
\hline
\end{tabular}

Table 7: Top patenting countries in USPTO in class 210 (Liquid Purification or Separation) 2000-2004

\begin{tabular}{|l|c|}
\hline Japan & 987 \\
Germany & 453 \\
Taiwan & 207 \\
Canada & 193 \\
United kingdom & 173 \\
France & 148 \\
South Korea & 84 \\
Israel & 71 \\
Sweden & 55 \\
Australia & 45 \\
Switzerland & 39 \\
Italy & 34 \\
Austria & 28 \\
Netherlands & 23 \\
Finland & 19 \\
South Africa & 18 \\
China,Hong Kong S.A.R. & 13 \\
Singapore & 10 \\
\hline
\end{tabular}

Table 8: Top patenting countries in USPTO in class 340 (Communications: Electrical) 2000-2004 


\begin{tabular}{|l|c|}
\hline Germany & 317 \\
Japan & 272 \\
Italy & 149 \\
Canada & 101 \\
Switzerland & 89 \\
Netherlands & 53 \\
France & 52 \\
Sweden & 43 \\
Austria & 42 \\
United Kingdom & 40 \\
Denmark & 23 \\
Taiwan & 20 \\
Finland & 16 \\
Australia & 15 \\
Spain & 13 \\
South Korea & 12 \\
South Africa & 10 \\
Norway & 7 \\
Belgium & 5 \\
\hline
\end{tabular}

Table 9: Top patenting countries in USPTO in class 198 (Conveyors: Power-driven) 2000-2004

\begin{tabular}{|l|c|}
\hline Japan & 452 \\
Germany & 246 \\
France & 137 \\
Canada & 80 \\
United Kingdom & 66 \\
South Korea & 40 \\
Netherlands & 26 \\
India & 25 \\
Italy & 25 \\
Denmark & 23 \\
Sweden & 23 \\
Australia & 22 \\
Belgium & 19 \\
Taiwan & 19 \\
Finland & 17 \\
Norway & 17 \\
China P. Rep. & 15 \\
Russian Federation & 14 \\
South Africa & 13 \\
\hline
\end{tabular}

Table 10: Top patenting countries in USPTO in class 423 (Chemistry of Inorganic Compounds) 2000-2004 


\begin{tabular}{|l|c|}
\hline Japan & 2347 \\
Germany & 2246 \\
France & 609 \\
United Kingdom & 600 \\
Switzerland & 373 \\
Italy & 282 \\
India & 272 \\
South Korea & 252 \\
Netherlands & 218 \\
Canada & 203 \\
Taiwan & 114 \\
Israel & 113 \\
Belgium & 102 \\
Sweden & 92 \\
Austria & 68 \\
Denmark & 68 \\
Australia & 66 \\
Spain & 63 \\
Finland & 56 \\
Hungary & 43 \\
Russian Federation & 31 \\
China P. Rep. & 27 \\
Norway & 25 \\
South Africa & 13 \\
\hline
\end{tabular}

Table 11: Top patenting countries in USPTO in class 532 (Conveyors: Power-driven) 2000-2004

Table 13 summarises South Africa's ranking in the technology classes in which the country produced more than 10 patents over the five- year period 2000-2004. South Africa is in $4^{\text {th }}$ position in class 518, 'Chemistry: Fischer-Tropsch Processes', and $12^{\text {th }}$ in class 075 , 'Specialised Metallurgical Processes...'. The technology classes in Table 13 reveal the technological areas in which South Africa has internationally recognised expertise.

Table 14 shows the number of patents that have been co-invented between a South African and a foreign inventor (patents with at least two co-inventors declaring different country address). During the period 2000-2004 there were 117 co-invented patents out of the 556 patents granted to South African inventors (21\%). The USA is the main technological collaborator with South Africa, with $37 \%$ of the collaborative efforts (43 patents). Germany and the UK follow with 22 and 18 patents respectively.

Table 15 shows the companies appearing as first assignees in the set of South African patents during 2000-2004 and during 1969-2004. The table shows that SASOL Technology Ltd had the most patents during the more recent 5-year period. It is interesting to note that there are a number of companies with substantial patenting activity during the period 19692004 and limited activity during the more recent period. For example, AECl appears with 41 patents during 1969-2004, but with only one patent during 2000-20004. It would be 
important for policy purposes to identify the reasons for the decline (e.g. closed down, bought/merged with another organisation, etc). It should be mentioned that the above data do not take into account changes in ownership after the award of patents, and they are only indicative of intellectual property owned by particular organisations, as organisations may own IP through other organisations locally and abroad or other types of agreements

\begin{tabular}{|l|c|}
\hline Japan & 2800 \\
Germany & 2417 \\
France & 1819 \\
United Kingdom & 1775 \\
Canada & 980 \\
Italy & 554 \\
Switzerland & 406 \\
Sweden & 400 \\
Israel & 351 \\
Denmark & 317 \\
Australia & 273 \\
South Korea & 271 \\
Belgium & 253 \\
Netherlands & 248 \\
India & 246 \\
Taiwan & 120 \\
Spain & 117 \\
China P. Rep. & 94 \\
Finland & 93 \\
Austria & 72 \\
New Zealand & 70 \\
Norway & 64 \\
Hungary & 54 \\
Russian Federation & 45 \\
Ireland & 40 \\
Argentina & 33 \\
South Africa & 22 \\
\hline
\end{tabular}

Table 12: Top patenting countries in USPTO in class 424 (Drug, Bio-Affecting and Body Treating Compositions) 2000-2004

\begin{tabular}{|ll|l|}
\hline Class & Ranking \\
\hline 518 & Chemistry: Fischer-Tropsch Processes & 4 \\
075 & Specialized Metallurgical Processes & 12 \\
210 & Liquid Purification or Separation compositions & 17 \\
198 & Conveyors: Power Driven & 18 \\
423 & Chemistry of Inorganic Compounds & 20 \\
532 & Organic Compounds & 25 \\
424 & Drug, Bio-Affecting and Body Treating Compositions & 28 \\
\hline
\end{tabular}

Table 13: International ranking of South Africa according to technology class 


\begin{tabular}{|l|c|c|}
\hline Country & Number of patents & Percentage \\
\hline USA & 43 & 37 \\
Germany & 22 & 19 \\
UK & 18 & 15 \\
Australia & 8 & 7 \\
Canada & 7 & 6 \\
Switzerland & 5 & 4 \\
Netherlands & 4 & 3 \\
France & 3 & 3 \\
Sweden & 2 & 2 \\
South Korea & 2 & 2 \\
Poland & 1 & $<1$ \\
Ireland & 1 & $<1$ \\
Israel & 1 & 100 \\
\hline Total & 117 & $<1$ \\
\hline
\end{tabular}

Table 14: Number of patents with co-inventors from other countries: SA 2000-2004

\begin{tabular}{|l|c|c|}
\hline First Named Assignee & 2000-2004 & 1969-2004 \\
\hline SA Invention Development Corp & 0 & 80 \\
AECI & 1 & 41 \\
CSIR & 8 & 36 \\
Rotary Profile Anstalt & 0 & 32 \\
SASOL Tech Ltd & 29 & 31 \\
MINTEK & 3 & 21 \\
Tobacco Research and Development Institute & 1 & 19 \\
Technology Finance Corp & 5 & 17 \\
Circuit Breaker Industries Ltd & 2 & 17 \\
DENEL & 6 & 14 \\
WRC & 6 & 14 \\
Windsor Tech Ltd & 11 & 11 \\
Implico BV & 5 & 9 \\
ESKOM & 4 & 8 \\
Ipcor NN & 6 & 6 \\
SASOL Chemical Industries & 1 & 6 \\
Sentrachem Ltd & 0 & 6 \\
Supersensor Ltd & 6 & 6 \\
University of Pretoria & 3 & 6 \\
Claas Selbstfahrende Entemaschinen GMBH & 5 & 5 \\
\hline & & \\
\hline
\end{tabular}

Table 15: Companies appearing as first assignees in the set of South African patents during 2000-2004 and during 1969-2004 
Table 16 shows the number of South African PCT international applications. The table shows that even though more than 300 inventors utilise the service, less than half go ahead to protect their invention through an application in an international patent office. While there are a number of different reasons for this gap (e.g. applications are identified as deficient, patents are applied for through other patent offices, etc) it is interesting from a policy perspective to identify the reasons behind the reluctance of inventors to proceed and protect their intellectual property.

\begin{tabular}{|c|c|}
\hline Year & Number of applications \\
\hline 1997 & 84 \\
1998 & 114 \\
1999 & 317 \\
2000 & 387 \\
2001 & 419 \\
2202 & 384 \\
2003 & 357 \\
2004 & 410 \\
2005 & 360 \\
\hline
\end{tabular}

Table 16: Number of PCT applications filed by South Africans, by date of filing

\section{SUMMARY AND DISCUSSION}

This article aims to identify and analyse the inventive activity of South African institutions. Inventive activity is analysed in terms of patents awarded to South African inventors by the USA Patent Office. As Griliches [3] has pointed out, "patent statistics remain a unique source for the analysis of the process of technical change. Nothing else even comes close in the quantity of available data, accessibility, and potential industrial, organizational, and technological detail”.

Our analysis indicates that South Africa has produced a constant stream of patents through the USPTO during the last 15 years. The technological class 518, 'Chemistry: FischerTropsch Processes; or Purification or Recovery of Products Thereof', appears to be the most inventive for South Africa. South Africa shares fourth position with France in that class. The Fischer-Tropsch process was developed by the German researchers Franz Fischer and Hans Tropsch, working at the Kaiser Wilhelm Institute in the 1920s. SASOL is one of only a few companies that have commercialized the Fischer-Tropsch technology.

South Africa occupies $12^{\text {th }}$ position in class 075 , 'Specialised Metallurgical Processes...'. Those technologies constitute the country's technological strengths, and government has the opportunity, in the national interest, to build upon them as technological platforms.

We further identified the most prolific SA companies in terms of patents, and the countries with which SA collaborates in the production of inventions.

An important finding is that South Africa appears not to have participated in the international explosion of patents during the last 15 to 20 years. During the past two decades most of the industrialised countries have experienced a substantial increase in patenting activity.

Two hypotheses have been offered to explain that increase: the pro-patent policy hypothesis [13]; [14] and the fertile technology hypothesis [15]; [16]; [17;]. Merges [13] has suggested that the jump in patenting activity reflects an increase in the propensity to patent inventions, driven by changes in the legal environment for patent holders. The recent international surge in patent applications may be a direct consequence of a major 
institutional change. Since the $8^{\text {th }}$ round of General Agreements on Tariffs and Trade (GATT), industrialized countries have changed their standards for protecting intellectual property via patents. The changes have not only broadened the rights of patentees, but have also strengthened the protection of intellectual property rights. These changes have been widely regarded as 'pro-patent', and, it has been argued, they are reflected in the increase in patent filing [17].

A different explanation for the recent jump in patenting stresses the type of technological revolution that has been widening the set of technological opportunities [16]. Connected with this is the explosion of new firm formation and innovation in the high-technology sector, particularly in the biotechnology, information technology, and software industries. Further, the application of information technology to the discovery process itself may have substantially increased the productivity of research and development [15]. Another possibility is that changes in the management of R\&D facilities, in particular a shift to more applied activities, have increased the yield of patentable innovations [18]. Still another possibility is that the increased level of patenting activity is the result of an overall increase in inventive input (higher levels of R\&D and/or changes in the composition of R\&D). The above set of ideas can be grouped together as the 'fertile technology hypothesis' to explain why patenting has surged.

As no substantial increase can be detected in the number of South African patents, it is reasonable to suggest that neither the policy environment nor factors determining technological fertility (as mentioned above) have changed in South Africa during the last two decades.

There are a variety of reasons that can be offered as possible explanations for the inability of the country to increase its number of patents in the USA market. Some of these are: the high cost of protection in the USPTO; the small number of large companies; the lack of high technology industries and research in the country; the orientation towards other sources of funding for universities and research councils; and others.

The Department of Science and Technology is currently introducing new legislation in order to address some of the above concerns. It will be important to monitor the effect that the introduction of the South African Intellectual Property Rights from Public-Financed Research Bill will have on inventive capacity in the country. However, it should be emphasized that the Bill affects only publicly-financed research and, as we discussed, the majority of patents internationally are produced by private organisations.

Finally, comparison of the various indicators identifies promising areas for further research. For example, we identify that a number of inventors utilise the PCT services, but only a limited number of them go ahead to apply for patents. Similarly a number of companies that were prolific patent holders in the past have stopped applying for patents. Why should that be? Answers to that question have the potential to provide policy insight and guidance.

\section{REFERENCES}

[1] DHEW. 1970. Towards a social report. Department of Health, Education and Welfare. University of Michigan Press, Ann Arbor.

[2] De Solla Price, D. 1975. The productivity of research scientists, in Yearbook of science and the future, Encyclopaedia Britannica Inc., University of Chicago, Chicago.

[3] Griliches, Z. 1990. Patent statistics as economic indicators: A survey. Journal of Economic Literature, 28 :1661-1707, p. 1702.

[4] Carr, K.F. 1995. Patents handbook: A guide for inventors and researchers to searching patent documents and preparing and making an application. McFarland and Co., Jefferson, NC and London. 
[5] OECD. 1994. The measurement of scientific and technological activities, using patent data as science and technology indicators - Patent manual, OECD, Paris.

[6] NSB. 2004. Science and engineering indicators - 2004, National Science Board, Arlington, VA: National Science Foundation.

[7] EC. 1997. Second European report on S\&T indicators 1997, European Commission, Directorate General XII. Science, Research and Development, Brussels.

[8] OECD. 2003. Main science and technology indicators, Organisation for Economic Cooperation and Development, Paris.

[9] Lubango, M.L. and Pouris A. 2007. Industry work experience and inventive capacity of South African academic researchers. Technovation: The International Journal of Technological Innovation, Entrepreneurship and Technology Management 27, 788796.

[10] Pouris, A. 2005. Technological performance judged by American patents awarded to South African inventors, SA Journal of Science, 101:221-224.

[11] Porter, M.E., Scott S. and the Council on Competitiveness. 1999. The new challenge to America's prosperity: Findings from the innovation index, COC: Washington

[12] Fordis, B.J. and Sung, M.L. 1995. How to avoid patent rejection, Bio/Technology 13, 42-43.

[13] Merges, R.P. 1992. Patent Law and Policy, Charlottesville, Virginia: Michie Company.

[14] Merges, R.P. 1995. Economic impact of intellectual property rights: An overview and guide. Journal of Cultural Economics, 19 (1995):103-17.

[15] Arora, A. and Gambardella A. 1994. The changing technology of technological change: General and abstract knowledge and the division of innovative labour. Research Policy, 23:523-32.

[16] Greenwood, J. and Yorukoglu M. 1997. 1974 Carnegie-Rochester Conference Series on Public Policy, 46:49-95.

[17] Kortum, S. and Lerner, J. 1997. Stronger protection or technological revolution: What is behind the recent surge in patenting? NBER Working Paper 6204, Cambridge, Mass.: National Bureau of Economic Research.

[18] Rosenbloom, R.S. and Spencer J.W. (1996). Engines of innovation: U.S. industrial research at the end of an era. Boston: Harvard Business School Press. 
http://sajie.journals.ac.za 